\title{
Implementation of Good Governance Business Sharia (GGBS) and Its Implications for Sharia Conformity and Profitability (SCnP) Financial Performance in Sharia Commercial Banks in Indonesia
}

Nindi Apriani, Kusnendi and Firmansyah

Indonesia Univerisity of Education

E-mail:_nindiapriani@student.upi.edu,kusnendi@upi.edu, firmansyah@upi.edu

\begin{abstract}
Financial performance is an analysis carried out to see the extent to which a company carries out the rules of implementing finances properly and correctly. The measurement of the financial performance of Islamic banks mostly still uses conventional measurement indicators namely profitability. This is considered less relevant, because the measurement of the performance of Islamic banks should be measured based on the suitability of sharia. Sharia Conformity and Profitability is a tool that measures the integrity of a bank, but still does not ignore the conventional side because the purpose of Islamic banks is to seek profit. This study aims to analyze the influence of Good Governance Business Sharia on Sharia Conformity and Profitability of Islamic Commercial Banks in Indonesia. The population in this study used all Islamic Commercial Banks (BUS) in Indonesia. The sample used was eleven Sharia Commercial Banks in Indonesia in 2012-2016. The method in this study uses explanatory research methods. The data analysis technique used is panel data regression. The results showed that the level of implementation of Good Governance Business Sharia was good enough and tended to increase. The Sharia Conformity and Profitability level of Islamic Commercial Banks in Indonesia has a high level of performance which means that the average performance is above on average. The implementation of Good Governance Business Sharia (GGBS) has a positive effect on Sharia Conformity but has a negative effect on Profitability. The results have important implications for Islamic Commercial Banks and regulator regarding Good Governance Business Sharia that should be modified as it aligns with sharia conformity but does not have impact on profitability.
\end{abstract}

Keywords. Financial performance, Sharia Conformity and Profitability, Good Governance Business Sharia.

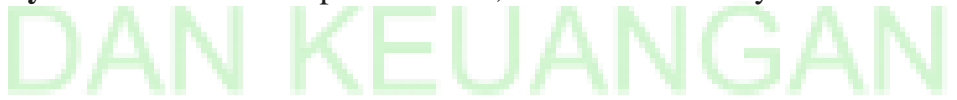

\section{INTRODUCTION}

Financial performance is an analysis conducted to see the extent to which the company has carried out using the rules of financial implementation properly and correctly (Fahmi, 2012). Measuring the financial performance of Islamic banks at present, mostly still use measurement indicators based on conventional financial ratios, especially profitability ratios such as ROA, ROE, and NPM whose purpose is to generate and increase profits (Asrori, 2014).

This is considered less relevant to the objective of Islamic banks being established as Islamic financial institutions, which are obliged to provide competitive banking products and services in accordance with Islamic principles (Iqbal \& Mirakhor, 2008). Thus, we need a model for measuring the performance of Islamic banks which is not only developed using profitability ratios, but also ratios that measure sharia compliance.

Therefore, we need a model of performance measurement of Islamic banks which is not only developed using conventional ratios, but also Islamic financial ratios. Some researchers in a number of countries have developed a combination of Islamic and conventional financial ratios, one of which is The Shariah and Profitability Mode / Model (SCnP).

Measurement with the SCnP Model is intended in addition to measuring the willingness of a bank, but not ignoring the conventional side, this is because the Islamic bank is also a business 
institution, one of the objectives of the establishment is to gain profit (Kuppusamy, Saleh, \& Samudhram, 2010).

The results of BUS performance measurements in Indonesia based on sharia conformity and profitability during the period 2010-2014 indicate that the majority of sharia commercial banks in Indonesia have high sharia suitability conditions, but low profitability or even low profitability and quite low sharia suitability values ( Prasetyowati \& Handoko, 2016).

This certainly becomes a problem that must be resolved immediately, efforts to improve the performance of Islamic banks must continue to be optimized better, so that the Indonesian people can distinguish the concepts and practices of Islamic banking that are not the same as conventional banks. In this regard, in achieving good financial performance, the management of Islamic banks must refer to governance standards and guidelines that are in accordance with Islamic principles in order to improve overall economic dynamics (Meilani, 2015). The implementation of good corporate governance or GCG is no longer a necessity but it is an essential for the company to run its business. The reason is that governance improvements greatly determine investment concern because it is able to attract investors to invest (Goza, 2014).

Therefore, in this case, the application of corporate governance / GCG of Islamic banking in Indonesia cannot merely be based on GCG principles in general as has been applied before. Although in principle these principles are in accordance with Islamic norms and values, Bank Indonesia has issued PBI regulation No. 11/33/ PBI/2009 concerning Good Corporate Governance for Sharia Banks and SE BI No.12/13/DPbS regarding GCG Implementation for Sharia Commercial Banks and Sharia Business Units that Sharia banking GCG must refer to governance standards and guidelines in accordance with Islamic principles (Bank Indonesia, 2009).

The National Committee on Governance Policy (KNKG) together with a number of institutions, such as the Sharia Economic Community (MES), Bank Indonesia, the National Sharia Council of the Indonesian Ulema Council (MUI) and so on have launched a corporate governance guideline for Islamic banks called the Good Governance Business Sharia (GGBS) guidelines, namely to complement PBI-2009 in implementing GCG in Islamic banking (National Committee on Governance Policy, 2011).

This GGBS Guideline is a guideline for implementing sharia business entity governance, especially sharia banks in Indonesia as an effort to encourage awareness and commitment to increase piety, benefit, and endowment in the business and sustainability of sharia business entities through management based on business practices with character and the characteristics of Rasulullah SAW (National Committee on Governance Policy, 2011). The idea of implementing GGBS is considered as a starting point for changes in work culture in Islamic banks. Islamic banks that apply the GGBS are expected to be able to run in accordance with the rules of sound practices in all fields (Meilani, 2016).

Thus, the implementation of sharia bank governance must be better than conventional banks, because in addition to carrying the name of sharia, the application of GCG in accordance with sharia principles is a form of accountability to the public that the sharia bank is professional and prudent while still trying to increase shareholder value ( shareholder value) (Faozan, 2014). Without an effective GCG, Islamic banks will be difficult to be able to strengthen its position, expand its network, and show its performance more effectively (Syukron, 2013).

Therefore, the existence of a Bank Indonesia Regulation (PBI) explicitly requires every sharia commercial bank and sharia business unit be required to disclose the implementation of GCG which includes sharia bank compliance disclosure (Saramawati \& Lubis, 2014). The implementation of GGBS in accordance with applicable regulations will make investors give a positive response to the company's performance and the company's market value (Meilani, 2015).

Understanding that the suitability of BUS and sharia principle is essential and aligning with profitability of the company is fundamental as well, thus the research problems that would be explored in this study are how far the extent of the implementation of GGBS and the Achievement of SCnP BUS in Indonesia? and whether the application of GGBS can improve Sharia Conformity and Profitability? The objectives of this research are to analyze the extent of the implementation of Good Governance Business Sharia (GGBS) and the achievement of Sharia Conformity and Profitability 
(SCnP) on Islamic commercial banks in Indonesia and to analyze the effect of Good Governance Business Sharia (GGBS) on Sharia Conformity and Profitability in sharia commercial banks in Indonesia.

Based on research conducted by Asrori (2014), Meilani (2015), Arieza \& Nugraheni (2016), Widiastuti \& Wulan (2017) and Siswanti, Salim, Sukoharsono, \& Aisjah, (2017) show that the application of Good Governance Business Sharia has a relationship significant and positive effect on the performance of Sharia Conformity and Profitability (SCnP). Thus, the research objective of this study is exploring whether there is a positive influence between the application of GGBS on SCnP in Indonesia for the period 2012-2016.

\section{LITERATURE REVIEW}

Performance is a general term used to indicate part or all of the actions or activities of an organization in a period (Mulyadi, 2001). According to Fahmi (2012) what is meant by financial performance is an analysis conducted to see the extent to which the company has carried out using the rules of financial implementation properly and correctly.

Measurement of the performance of Islamic financial institutions is something essential, as important as measuring the achievement of individuals. Due to the roles and responsibilities of Islamic finance are different from conventional financial institutions, which are not only limited to the financial needs of various parties, but the most important is how to conduct business and the actions used to ensure that all activities are in accordance with sharia (Meilani, 2015).

Sharia Conformity and Profitability (SCnP) is a measurement of sharia banking performance must use a measuring tool that shows the sharia side of sharia, but does not neglect the conventional side of profitability, this is because the sharia bank is also a business institution which one of the objectives set up is to get profit (Kuppusamy, Saleh, \& Samudhram, 2010). SCnP is measured by Islamic Inves

In the concept of sustainable Copnell (2002) in Syukron (2013), Corporate Governance as a system and process to direct and control the organization in order to improve performance and achieve shareholder value. The implementation of GCG in sharia banking is different from the practice of GCG in general, GCG banking aims to encourage sharia banking practices that are strong and financially sound and always refer to sharia principles (Bank Indonesia, 2009). The idea of implementing GGBS is a starting point for changes in work culture in Islamic banks (Meilani, 2015).

In this study, the independent variable is the application of GGBS with 42 indicators that can be described through the achievement of the GGBS Implementation Index in accordance with the guidelines that have been prepared. Meanwhile, the dependent variable is Sharia Conformity and Profitability with Sharia Conformity indicators namely Islamic Investment Ratio, Islamic Income Ratio and Profit Sharing Ratio. While the profitability indicators are ROA, ROE and NPM. Based on these indicators, the effect of GGBS on SCnP is then seen.

This is in line with research conducted by Kuppusamy, Saleh, \& Samudhram (2010), AlMamun, Yasser, \& Entebang (2014), Ratnaputri (2013) and Prasetyowati \& Handoko (2016) that it is important to measure BUS financial performance based on Sharia Conformity and Profitability (SCnP) in order to know the level of sharia and profitability of BUS. Furthermore, Asrori (2014), Safieddine (2009), Siswanti, Salim, Sukoharsono, \& Aisjah (2017), Meilani (2015), Arieza \& Nugraheni (2016), Widiastuti \& Wulan (2017), and Holili (2017) reveal that Good corporate governance of Islamic banks has a positive effect on Islamic and conventional financial performance. Thus, it can be assumed that GGBS has a positive effect on SCnP.

The similarity with previous studies is to examine the relationship between GGBS variables and Islamic Bank Performance. Meanwhile, the difference is that previous studies only analyzed the application of GGBS and tested the relationship of other variables with GGBS. The uniqueness of this research with the previous research is that the work measurement model used is Sharia Conformity and Profitability. So that the application of GGBS is tested for its effect on ScnP. 


\section{RESEARCH METHODOLOGY}

The research method used in this study is explanatory method. Explanatory or explanatory research aims to explain the relationship between two or more variables. Explanatory research is also research that identifies various variables outside the problem to confirm the cause of a problem (Silalahi, 2012).

The object in this study relates to the performance of Islamic banking as measured by sharia conformity and profitability ratios or SCnP Models and the application of Good Governance Business Sharia (GGBS). The study was conducted on Islamic Commercial Banks (BUS) in Indonesia for the 2012-2016 period, amounting to 13 banks. Sampling in this study was conducted by purposive sampling chosen based on judgment (judgment sampling). According to Ferdinand (2014) sample selection based on judgment sampling is adjusted to the research or research problem developed. Then, there are 11 BUS that meet the specified criteria.

In this study the data analysis technique used is the panel data regression method. Panel data is a combination of cross section (cross section) and time series data (Rohmana, 2013). Meanwhile, for processing data using EViews software 9. The steps taken in the panel data regression method are as follows:

\section{a. Determination of Panel Data Regression Model}

In analyzing panel data, an appropriate model specification test is needed to describe the data. Chow test, Hausman test and Lagrange multiplier (LM) test (Rohmana, 2013).

\section{b. Classic Assumption Tests}

Basuki \& Prawoto (2016) suggested that the classic assumption test used in linear regression with the Ordinary Least Square (OLS) approach includes tests of normality, linearity, multicollinearity, heteroscedasticity, and autocorrelation.

\section{c. Hypothesis Testing}

1) Test t

Hypothesis testing is to compare between $t$ arithmetic and $t$ table. If $t$ arithmetic is greater than $\mathrm{t}$ table ( $\mathrm{t}$ arithmetic $>\mathrm{t}$ table), then the hypothesis is accepted. In addition, to see the significance can be seen from the value of the probability. If the probability value $<0.05$ then rejects Ho and accepts $\mathrm{Ha}$, conversely if the probability value $>0.05$ then accepts Ho and rejects Ha. Based on the previous research and the objective of this study, the following is the formulation of the proposed hypothesis:

For the Implementation of GGBS Against Sharia Conformity

H1: The application of GGBS has a positive effect on Sharia Conformity.

For the Implementation of GGBS on Profitability

H2: The application of GGBS has a positive effect on profitability

2)

\section{The coefficient of determination}

According to Rohmana (2013) the coefficient of determination (R2) explains how much the total percentage of the variation of the dependent variable explained by the model, the greater R2 the greater the influence of the model in explaining the dependent variable. R2 values range from 0 to 1 $(0<\mathrm{R} 2<1)$, an $\mathrm{R} 2$ of 1 or close to 1 means that there is a strong influence of the independent variable that is able to explain the dependent variable, and vice versa.

\section{RESULTS AND DISCUSSION}

\section{Level of Application of GGBS BUS in Indonesia}

Based on research data it can be seen that the level of GGBS disclosure by all BUS in Indonesia in this study tends to increase, with a fairly high percentage of above 80 percent. Although in 20122013 there was a decrease of $80.95 \%$ from $81.2 \%$ but the decrease was not so significant. The increase in the percentage of GGBS disclosures occurred in 2013-2016 with disclosure rates of $83.33 \%$, $84.20 \%$ and $86.80 \%$, respectively. Thus, if seen from the percentage range of $80-86 \%$ with the fulfillment of an average index score of 35, it can be said that overall the implementation of GGBS by BUS in Indonesia during the 2012-2016 period has been well implemented.

From the overall total disclosure score it can be seen that BNIS received the highest disclosure score of 188 indicators. Based on its annual report, in the disclosure of GGBS as many as 42 indicators, BNI Syariah Bank is the most complete bank expressing the GGBS implementation index 
compared to other Islamic banks.

\section{Sharia Conformity and BUS Profitability Level in Indonesia}

In general, it can be seen that the performance analysis using Islamic bank SCnP is spread over four quadrants and the average condition of 11 BUS in Indonesia during the 2012-2016 period is mostly located in the Upper Right Quarant (URQ) position. The calculation results show that of the 55 total research points, 21 URQ points, 20 ULQ points, 5 LRQ points, and the remaining 9 LLQ points.

The dominance of the URQ point is indicated that in general BUSs in Indonesia have high Islamic compatibility and a high level of profitability. In this study, Bank Muamalat Indonesia and BCA Syariah Bank were the banks with the best SCnP performance because they were able to consistently be in the URQ position. While the bank with the lowest performance is Mega Syariah Bank, this is because for 3 years BMS has occupied the LLQ position.

\section{Hypotheses Testing and Discussion}

\section{a. The Application of GGBS towards Sharia Conformity}

The coefficient of determination explains how much the percentage of the total variation of the dependent variable explained by the model, the greater the value of R2 the greater the model's influence in explaining the dependent variable. Based on the regression results obtained $\mathrm{R} 2$ value of 0.84639 and Adjusted R-squared value of 0.807105 , meaning that the level of closeness of the influence of $\mathrm{X}$ or GGBS variables on the Y1 or Sharia Conformity variables is quite large, reaching $84.639 \%$, while the remaining $15.360 \%$ is influenced by other variables outside this research.

The regression test conducted in this study is a partial regression test $(\mathrm{t}$ test) where the hypothesis proposed is to test how much influence the application of GGBS on Sharia Conformity is projected with Islamic investment, Islamic Income and profit sharing ratio. T table value is obtained from the $t$ distribution table, which is seen from the value of degrees of freedom (df) and $\alpha$. Where $\mathrm{df}$ $=\mathrm{n}-\mathrm{k}=55-2=53$ and $\alpha=5 \%(0.05)$, the $\mathrm{t}$ table value is 1.67412 .

Then the $t$ value of this table will be compared with the calculated value of $t$ As for the details of the results of the regression test using the independent variable $t$ test to the dependent variable as follows.

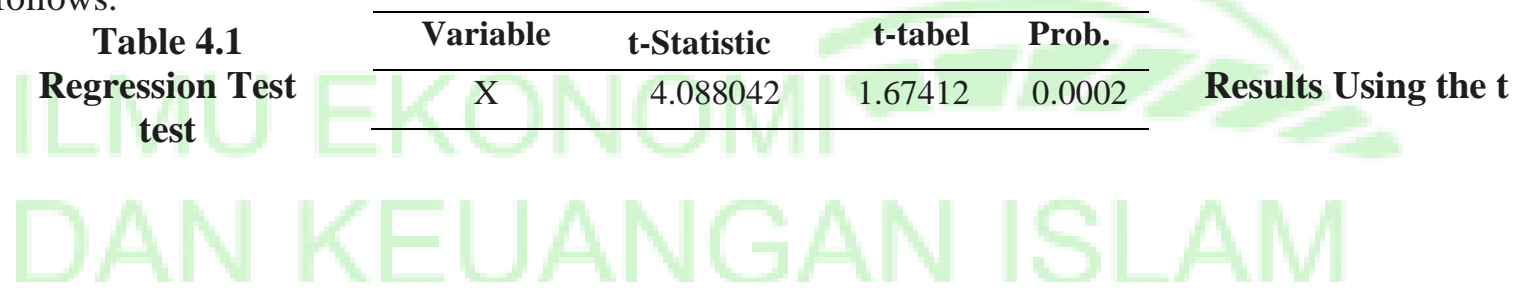

Based on the $t$ value of the independent variable shows a greater result than the value of $t$ table, then $\mathrm{HO}$ is rejected and $\mathrm{Ha}$ is accepted. Then the probability value of $\mathrm{t}$ is below the significance value of 0.05 which is 0.0002 so from the results of this test it can be concluded that $X$ or the application of GGBS has a positive and significant effect on Y1 or Sharia Conformity. The coefficient of applying GGBS is 0.514603 which means that every increase in GGBS disclosure in the annual report of the BUS will affect the level of sharia conformity of 0.514603 .

Based on the results of the $t$ test which shows that the application of Good Governance Business Sharia has a positive and significant effect on financial performance based on sharia compliance or sharia conformity. In general, this is in accordance with the concept of corporate governance proposed by Sharman and Copnell (2002), that corporate governance as a system and process for directing and controlling an organization in order to improve performance and achieve sustainable shareholder value. Thus, this concept states that companies that implement good corporate governance or good corporate governance, also have good financial performance.

The GGBS concept put forward by the National Governance Policy Committee (2011) is the implementation of GCG for Sharia Commercial Banks and Sharia Business Units and other Business Companies with the aim of encouraging strong, financially sound business practices and referring to sharia principles. Where business is guided by spirituality and ethics will create a healthy and 
sustainable business climate with the realization of market discipline born from a culture of good business governance.

In testing this first hypothesis, where the results show a significant influence between GGBS on sharia conformity, the implementation of GGBS is illustrated through the GGBS Implementation Index which is reflected in the disclosure of GGBS indicators in its annual report. Whereas for measuring the financial performance of an Islamic bank, it is measured based on sharia conformity which is an index of conformity of the sharia system with the aim of assessing the socio-economic obligations of an Islamic bank.

The results of this study are in line with the results of previous studies such as the research of Arieza \& Nugraheni (2016) Siswanti, Salim, Sukoharsono, \& Aisjah (2017), Widiastuti \& Wulan (2017) which show that GBBS has a significant effect on the Islamic financial performance index . Similarly with Asrori's research (2014) which states that the implementation of Islamic corporate governance (ICG) or Islamic corporate governance that measures the implementation of DPS and Sharia Compliance duties and responsibilities, which in this case is included in the indicators of GGBS implementation has a positive effect on the performance of Islamic banks. measured using sharia conformity financial ratios.

This study also has differences with the results of research conducted by Kurniawan (2016) and Jumansyah \& Syafei (2013) which states that the application of GGBS does not have a significant influence on Islamic performance. This is because although the principles of Islamic corporate governance have been implemented but have not been able to make a significant contribution to the performance of Islamic banks.

The higher level of implementation of GGBS, which means that Islamic business companies manage their companies well in accordance with Islamic guidelines and rules, will also increase the ability of Islamic banks to achieve Islamic goals including certainty in the implementation of all their activities in accordance with sharia. Therefore, it is important for all BUSs in Indonesia to manage their companies properly. This aims to improve the performance of Islamic banking companies as Islamic financial institutions, which are primarily Islamic company performance that is measured using Islamic compatibility ratios.

The results of this study also provide empirical support for the recommendations of Islamic economics and financial experts Lewis (2005), Hasan (2008) and Bhatti \& Bhatti (2010) which state that the implementation of Islamic corporate governance in carrying out operational activities and banking businesses will improve the performance of banking companies sharia as an Islamic financial institution.

In addition, the results of this study also illustrate the success of Bank Indonesia Regulation No. 11/33 / PBI / 2009 concerning the Implementation of Good Corporate Governance for BUS and UUS, through the implementation of the duties and responsibilities of the Board of Commissioners and Directors, the completeness of tasks and the implementation of the committee's functions and functions that carry out the BUS's internal control, the implementation of DPS's duties and responsibilities, the application of compliance functions, internal and external audits, maximum limits on fund distribution, and transparency of BUS financial and non financial conditions.

So it can be concluded that when the implementation of the GGBS has been implemented properly, which means that information related to Islamic banks is delivered properly and in accordance with Islamic principles by every BUS in Indonesia to its shareholders and stakeholders, then this will foster shareholder trust, customers, investors and even the general public towards Islamic banks. So that it will also have an impact on increasing the financial performance of Islamic financial institutions as measured by Sharia conformity.

\section{b. The Application of GGBS towards Profitability}

The coefficient of determination explains how much the percentage of the total variation of the dependent variable explained by the model, the greater the value of R2 the greater the model's influence in explaining the dependent variable. Based on the regression results shown in Table 4.34, the $\mathrm{R} 2$ value is 0.330551 and the Adjusted R-squared value is 0.159297 . This means that the closeness of the influence of the X or GGBS variable to the Y2 variable or profitability is a low coefficient of determination because it is below 50 percent or only 33, 0551\%. The reason for the low value of R2 
is that the GGBS variable has not been able to provide the information needed to predict an increase in profitability.

Regression test conducted in this study is a partial regression test ( $\mathrm{t}$ test) where the hypothesis proposed is to test how much influence the application of GGBS on Profitability that is projected with ROA, ROE and NPM.

$\mathrm{T}$ table value is obtained from the $\mathrm{t}$ distribution table, which is seen from the value of degrees of freedom (df) and $\alpha$. Where $\mathrm{df}=\mathrm{n}-\mathrm{k}=55-2=53$ and $\alpha=5 \%(0.05)$, the $\mathrm{t}$ table value is 1.67412 . Then the $t$ value of this table will be compared with the calculated $t$ value. The details of the results of the regression test using the $t$ test independent variables on the dependent variable are explained as follows.

Table 4.2 Regression Test Results Using the $t$ Test (X Against Y2)

\begin{tabular}{cccl}
\hline Variable & t-Statistic & t-tabel & Prob. \\
\hline $\mathrm{X}$ & 1.8420 & 1.6741 & 0.0724 \\
\hline
\end{tabular}

Based on the $t$ value, the independent variable shows a greater result than the $t$ table value, which means that the application of GGBS has a negative effect on profitability. The direction of the negative relationship can be interpreted that the application of high Islamic bank corporate governance, the bank's performance will be low, and vice versa. In connection with the results of the hypothesis, this rejects the hypothesis and is not in line with existing theories. Because basically the implementation of corporate governance mechanism aims to provide progress towards the performance of a company, one of which is the company's profitability or profit seeking (Riandi \& Siregar, 2011).

The negative effect of the application of GGBS on profitability based on the results of research conducted by Tertius \& Christiawan (2015) who conducted research on "The Effect of Good Corporate Governance on Company Performance in the Financial Sector" found that the higher the proportion of independent directors, the company's ROA would decrease (company ability in the case of low profitability), which shows that when the implementation of corporate governance has been disclosed properly, including disclosed by an independent board of commissioners and other indicators, investors are actually reluctant to invest their shares. This is because when the proportion of independent directors is too large, the performance is not effective.

The results of this study are also in line with research conducted by Pandya (2011) using a sample of the banking industry in India. The results of his research indicate that the proportion of independent commissioners who are part of the implementation of corporate governance negatively affects ROA. This means that too many proportions of independent directors have an inverse relationship with ROA.

Other results similar to this study are those conducted by Aroyinde, Toyin, \& Leye (2012) on "Evaluating the Effects of Corporate Governance on the Performance of the Nigerian Banking Sector" which examines the effects of corporate governance on Nigerian banking performance. The sample of this study was 24 commercial banks in Nigeria during the period 2006-2010. The research variables used are the size of the board of commissioners, performance, return on equity and directors 'equity results proving that there is a negative relationship between board size and bank performance while the percentage increase in return on equity is influenced by directors' equity, but there is no uniformity in disclosure of governance practices company conducted by a bank in Nigeria.

From some of the presentations it can be concluded that the application of GGBS on BUS in Indonesia has not been able to contribute to improving the financial performance of Islamic banking which is projected with ROA, ROE and NPM. The good implementation of Sharia Business Governance on BUS in Indonesia in fact results in a negative relationship to financial performance as measured by profitability ratios.

\section{CONCLUSION}

In general, the level of implementation of Sharia Good Bank Syariah Business Governance in Indonesia in this study is quite good and tends to increase, with a fairly high percentage. BNI Syariah Bank is the highest Syariah Bank in the disclosure of GGBS, while the lowest rank is fulfilled 
by BJBS Syariah. Achievement of Sharia Commercial Bank financial performance in Indonesia based on measuring instruments of sharia conformity and profitability is spread over four quadrants and the average condition of 11 BUS in Indonesia during 2012-2016 is largely located in the Upper Right Quarant (URQ) position. This indicates that in general BUSs in Indonesia have high Islamic compatibility and a high level of profitability.

The implementation of Good Governance Business Sharia (GGBS) has a significant positive effect on Sharia Conformity of Islamic Commercial Banks in Indonesia. This shows that when the level of implementation of corporate governance in accordance with Islamic principles is high in Islamic banks, the level of Islamic financial performance that is sharia conformity is also high. The implementation of Good Governance Business Sharia (GGBS) has a negative effect on the profitability of Islamic Commercial Banks in Indonesia. This means that any increase in GGBS that occurs in Islamic banks results in a decrease in the profitability performance of Islamic banks. The results have important implications for Islamic Commercial Banks and regulator regarding Good Governance Business Sharia that should be more in concern and need to be modified as it aligns with sharia conformity but does not have impact on profitability.

\section{REFERENCE}

Arieza, R. F., \& Nugraheni, P. (2016). Pengaruh Penerapan Good Governance Bisnis Syariah, Ukuran Perusahaan, dan Leverage Terhadap Kinerja Perbankan Syariah (Studi Komparasi Pada Perbankan Syariah di Indonesia dan Malaysia Tahun 2012-2015). Jurnal Magister Akuntansi, Vol 5, No. 1, 1-30.

Aroyinde, A. O., Toyin, A., \& Leye, A. (2012). Evaluating the Effects of Corporate Governanceon the Performace of Nigerian Banking Sector. Review of Contemporary Business Research Vo, 1, No, 1, 32-42.

Asrori. (2014). Implementasi Islamic Corporate Governance dan Implikasinya Terhadap Kinerja Bank Syariah. Jurnal Dinamika Akuntasi Vol.6, No.1, ISSN 2085-4277, 90-102.

Bank Indonesia. (2009). Peraturan Bank Indonesia Nomor 11/ 33/PBI/2009 Tentang Pelaksanaan Good Corporate Governance Pada Bank Umum Syariah dan Unit Usaha Syariah. Jakarta: Bank Indonesia.

Basuki, A. T., \& Prawoto, N. (2016). Analisis Regresi dalam Penelitian Ekonomi \& Bisnis. Depok: PT Rajagrafindo Persada.

Bhatti, \& Bhatti. (2010). Toward Understanding Islamic Corporate Governance Issues In Islamic Finance. Asian Politics and Policy, Vo.2, No.2, 25-38.

Fahmi, I. (2012). Analisis Kinerja Keuangan . Bandung: Alfabeta.

Faozan, A. (2014). Implementasi Shariah Governance di Bank Syari'ah. Asy-Syir'ah Jurnal Ilmu Syari'ah dan Hukum Vol. 49, No. 1, 339-340.

Goza, D. G. (2014, Desember 10). GCG Bukan Keharusan Tapi Kebutuhan. Retrieved November 17, 2017, from BeritaSatu.com: http://www.beritasatu.com/emiten/232012-gcg-bukankeharusan-tapi-kebutuhan.html

Hasan, Z. (2008). Regulatory Framework of Shari'ah Governance System in Malaysia, GCG Countries and the UK. Kyoto Buletin of Islamic Area Studies, Vol.3, No.2, 82-115. 
Hisamuddin, N., \& Tirta, M. (2013). Pengaruh Good Corporate Governance Terhadap Kinerja Keuangan Bank Umum Syariah. Jurnal Akuntansi Universitas Jember Vol. 11, No 2, 109137.

Iqbal, \& Mirakhor. (2008). Stakeholder Model Of Corporate Governance in Islamic Economic System. Islamic Economi Studies, Vol. 11, 43-64.

Jumansyah, \& Syafei, A. W. (2013). Analisis Penerapan Good Governance Business Syariah dan Pencapaian Maqashid Shariah Bank Syariah di Indonesia. Jurnal Al-Azhar Indonesia Seri Pranata Sosial, Vol. 2, No. 1, 26.

Komite Nasional Kebijakan Governance. (2011). Pedoman Umum Good Governance Bisnis Syariah. Jakarta: Komite Nasional Kebijakan Governance (KKNG).

Kuppusamy, M., Saleh, A. S., \& Samudhram, A. (2010). Measurement Of Islamic Banks Performance Using a Syariah Conformity and Profitability Model. Review of Islamic Economics, 13 (2), $35-48$.

Kurniawan, H. (2016). Pengaruh Intellectual capital, Islamic Corporate Governance, Islamic Social Responsibility, Islamic Ethical Identity dan Zakat Terhadap Kinerja Keuangan Bank Syariah. Tesis UIN Sunan Kalijaga.

Lewis. (2005). Islamic Corporate Governance. Review of Ilamic Economic, Vo. 9, 5-29.

Meilani, S. E. (2015). Hubungan Penerapan Good Governance Business Syariah Terhadap Islamicity Financial Performance Index Bank Syariah di Indonesia. Seminar Nasional dan The 2nd Call for Syariah Paper ISSN 2460-0784, 182-196.

Meilani, S. E. (2016). Penerapan Good Governance Business Syariah (GGBS) dan Voluntary Disclosure (Studi Pada Perusahaa Perbankan Syariah di Indonesia Periode 2010-2014). Jurnal Eka Cida Vol 1 No. 1 Maret 2016 ISSN: 2503-3565 e-ISSN: 2503-3689, 127.

Mulyadi. (2001). Sistem Akuntansi. Yogyakarta: STIE YKPN.

Otoritas Jasa Keuangan. (2017). Statistik Perbankan Syariah Desember 2017. Jakarta: Otoritas Jasa Keuangan, Republik Indonesia.

Pandya, H. (2011). Corporate Governance Structure and Financial Performance of Selected Indian Banks. Journal of Management \& Public Policy 2(2), 4-21.

Prasetyowati, L. A., \& Handoko, L. H. (2016). Pengukuran Kinerja Bank Umum Syariah dengan Maqasid Index dan Sharia Conformity and Profitability. Jurnal Akuntasi dan keuanganISlam Vol. 4, No.2, 107-130.

Prasojo. (2015). Pengaruh Penerapan Good Corporate Governance terhadap Kinerja Keuangan Bank Syariah. Jurnal Dinamika Akuntansi dan Bisnis Vol. 2, No. 1, 59-69.

Pratiwi, A. (2016). Pengaruh Kualitas Penerapan Good Corporate Governance (GCG) terhadap Kinerja Keuangan pada Bank Umum Syariah di Indonesia (Periode 2010-2015). Al-Tijary 
Jurnal Ekonomi dan Bisnis Islam Vol. 2, No. 1, P-ISSN: 2460-9404; E-ISSN: 2460-9412 DOI prefix : $10.21093,55-76$.

Ratnaputri, W. (2013). The Analysis of Islamic Bank Financial Performance By Using CAMELS, Sharia Conformity and Profitability (SCnP). Jurnal Dinamika Manajemen Vol.4 No.2, 220 232.

Riandi, D., \& Siregar, H. S. (2011). Pengaruh Penerapan Good Corporate Governance Terhadap Return on Assets, Net Profit Margin, Earning Per Share Pada Perusahaan yang Terdaftar di Corporate Governance Perception Index. Jurnal Ekonomi Vo. 14, No.1, 127-133.

Rohmana, Y. (2013). Ekonometrika Teori dan Aplikasi dengan Eviews. Bandung: Laboratorium Pendidikan Ekonomi dan Koperasi, FPEB, UPI.

Saramawati, D. A., \& Lubis, A. T. (2014). Analisis Pengungkapan Sharia Compliance dalam Pelaksanaan Good Corporate Governance Bank Syariah di Indonesia. Jurnal Akuntansi dan Keuangan Islam 2, No. 2, 107-110.

Silalahi, U. (2012). Metode Penelitian Sosial. Bandung: PT Refika Aditama.

Siswanti, I. (2016). Implementasi Good Corporate Governance Pada Kinerja Bank Syariah. Jurnal Akuntansi Multiparadigma JAMAL Vol.7 No.2 ISSN 2086-7603 e-ISSN 2089-5879, 156-323.

Susana, E., \& Prasetyanti, A. (2011). Pelaksanaan dan Sistem Bagi Hasil Pembiayaan Al-Mudharabah Pada Bank Syariah. Jurnal Keuangan dan Perbankan, Vol.15, Terakreditasi SK. No. 64a/DIKTI/Kep/2010, 466-478.

Syafei, A. W. (2013). Analisis Pengaruh Penerapan Good Governance Bisnis Syariah (GGBS) terhadap Kemampulabaan (Studi Perusahaan yang Terdaftar di JII 2011). Jurnal Al-Azhar Indonesia Seri Pranata Sosial, Vol . 2, No. 2, September 2013, 74-75.

Syukron, A. (2013). Good Corporate Governance di Bank Syariah. Economic Jurnal Ekonomi dan Hukum Islam, Vol. 3, No.1 ISSN: 2088-6365, 60-83.

Tertius, M. A., \& Christiawan, Y. J. (2015). Pengaruh Good Corporate Governance terhadap Kinerja Perusahaan pada sektor Keuangan. Business Accounting Review Vol. 3, No. 1., 223-232.

Tikawati. (2012). Implementasi Good Corporate Governance Pada Lembaga Keuangan Syariah (Perbankan Syariah). Jurnal Pemikiran Hukum Islam Vol. 10, No.2, 118-126. 